\title{
On the Role of Livland \\ Pastors in Processes of \\ Cultural Exchange During the Eighteenth Century
}

\begin{abstract}
Priit Raudkivi
Tallinn University, School of Humanities, Centre of History, Archaeology and Art History, Uus-Sadama 5, IOI20 Tallinn, priit.raudkivi@tlu.ee
\end{abstract}

\begin{abstract}
This article sheds light on the patterns of filling pastoral positions in the Latvian-language area of Livland province, i.e. the Vidzeme rural parishes. Above all, attention is given to the education background of the pastors who imparted biographical information in the published church archives and how their path to become a pastor progressed. Secondly, the problem of pastors' self-image is examined. Thirdly, an attempt is made to find out whether the church materials deposited in the general framework of the Swedish Church Law of 1686 may reflect the intellectual impulses received by pastors from German universities. The focus is on whether the increased interest in the state of the physical environment, above all weather, as one of the manifestations of the enlightened worldview, is reflected in church chronicles.
\end{abstract}

Keywords: Livland, Enlightenment, protestant clergy, cultural transfer, environmental history

\section{INTRODUCTION}

Johann Christoph Petri (I752-I851), a keen observer and critic of social conditions in the Baltic provinces of the Russian Empire, writes in his work published in 1802 about the recruitment of home teachers for the 
provinces. To find a suitable candidate, a German university was contacted, whose professors helped to find someone from within their academic community. ${ }^{1}$ In his book on August Wilhelm Hupel (I737-I819), Indrek Jürjo refers to the university lecturer as a kind of broker. ${ }^{2}$ Thus, at the time, universities were engaged in the mediation of "intellectual property", mainly for the teaching of children of the Estland and Livland nobility. In reality, the position of home teacher was a good starting point for an entrepreneurial young man who had studied theology to seek out and take advantage of favourable opportunities to advance within the social hierarchy. Even Hupel's own biography, although incomplete, testifies to this. In the autumn of ${ }_{1757}$, he arrived in Riga and probably started working as a home teacher in Äksi (Ger. Ecks) parish. In 1759, he passed the exam necessary for the pastoral office in Riga and was subsequently inaugurated into the pastoral office in Äksi in 1760 . From there, he was invited to be the pastor in Póltsamaa (Ger. Oberpahlen) in 1763 , and his term began the following year. ${ }^{3}$ Forty years of fruitful activity in the spirit of the Enlightenment follow.

Hupel's prominence as one of the leading figures of the Enlightenment in the Baltic provinces is so significant that it is often forgotten that he was by no means a man with roots in the region. Hupel, Friedrich Konrad Gadebusch (1719-1788), Johann Georg Eisen (1717-1779), and many other bearers (or, for that matter, "brokers") of Enlightenment ideas, in addition to descriptors and critics of local social conditions, were immigrants from Germany. Many of them are taken for granted in local cultural tradition as "one of our own", but they were only just becoming so. In reality, they were just the most prominent representatives of all those literati who migrated to the Baltic provinces from German lands.

One of the characteristic features of the history of Estonian and Latvian territories from the thirteenth to mid-nineteenth century is that society was unable to reproduce itself across the entire social spectrum. In these lands, a local statehood - characterised by the existence of a central government and efforts to ensure the fulfilment of all necessary social positions (primarily) utilising its own human resources - simply did not emerge. The need to create an institution of higher education

I Petri, J. C. Ehstland und die Ehsten, oder historisch-geographisch-statistisches Gemälde von Ehstland. Ein Seitenstück zu Merkel über die Letten. Dritter Theil. K. W. Ettinger, Gotha, 1802, 290-291.

2 Jürjo, I. Liivimaa valgustaja August Wilhelm Hupel. I737-I819. Riigiarhiiv, Tallinn, 2004, 37. However, there were other ways to recruit home teachers: Plath, U. Esten und Deutsche in den baltischen Provinzen Russlands. Fremdheitskonstruktionen, Lebenswelten, Kolonialphantasien 1750-1850. (Veröffentlchungen des Nordost-Instituts. Bd. Ir.) Harrassowitz, Wiesbaden, 20II, 47-49.

3 Jürjo, I. Liivimaa valgustaja, 42-43. 
to prepare domestic clergy had already been discussed in the early phase of the Reformation in late-medieval Livonia. It was clear that clergy trained in the Protestant spirit were in demand. However, the decision to set up a joint education institution was not agreed upon by the local leading political powers. The Hanseatic cities, for example, stated that they were satisfied with the current arrangements of bringing in trained clergy from Germany. ${ }^{4}$ This is evident from the fact that local society had been marked by quasi-colonial characteristics ${ }^{5}$ since Catholic colonisation in the thirteenth century and that the gaps in the social structure were compensated by people from the German cultural space. In this sense, the situation after the Great Northern War is a prime example of the urgent need to fill positions that are crucial to the functioning of society (such as teachers and clergy) through the procurement of educated German immigrants. Undoubtedly, there are several reasons for this: depopulation as a result of direct warring and, of course, the last plague rampant on the eastern shores of the Baltic Sea, which may have decimated up to $2 / 3$ of the population, regardless of social status. ${ }^{6}$ Such contributing factors might be termed "societal stress". In this way, the local community remained open to the German language and culture for reasons of objective pragmatism. The overproduction of intellectuals in Germany certainly encouraged the arrival of young university-trained men in Estland and Livland, where the need for people with higher education, or at least for those who had had a sniff of university air, was great. True, the University of Tartu (Ger. Dorpat), founded in 1632, had begun to fulfil these needs and early developments could already be seen in Sweden's Baltic provinces. Nevertheless, the period of operation of the university remained short. According to Arvo Tering, the ratio for the origin of pastors was $50 / 50$ (on the principle of local/immigrant) by the end of the eighteenth century, ${ }^{7}$ while Heinrich Bosse asserts the corresponding percentage was even 52 in favour of immigrants. ${ }^{8}$ Hupel himself states in his work published in 1777 : "Mehrere Ausländer als

4 Raudkivi, P. Tracing Social Change: The Case of Old Livonia. - Wandel und Anpassung in der Geschichte Estlands. 16.-20. Jahrhundert. Hrsg. von K. Brüggemann. (Nordost-Archiv. Zeitschrift für Regionalgeschichte, 22/2013.) Nordost-Institut, Lüneburg, 20I4, 32.

5 Raudkivi, P. Tracking Social Change, 19-20.

6 Palli, H. Eesti rahvastiku ajalugu aastani ı7ı2. Teaduste Akadeemia Kirjastus, Tallinn 1996, $75-76$.

7 Tering, A. Eesti-, liivi- ja kuramaalased Euroopa ülikoolides I56I-I798. Eesti Ajalooarhiiv, Tartu, 2008, 60I-603.

8 Bosse, H. Die Hofmeister in Livland und Estland. Ein Berufsstand als Vermittler der Aufklärung. - Aufklärung in den baltischen Provinzen Rußlands: Ideologie und soziale Wirklichkeit. Hrsg. von O.-H. Elias, in Verbindung mit I. Jürjo, S. Kivimäe. G. v. Pistohlkors. (Quellen und Studien zur baltischen Geschichte, I5.) Böhlau, Cologne et al., 1996, 190. 
Landeskinder sind hier Prediger". ${ }^{9}$ There was no principal change before the (re)establishment of the University of Tartu in 1802.

Sociological generalisations are essential for understanding societal processes. The above proportions of the origin of pastors also provide enough food for thought. First, a clear perspective is outlined to address the history of modern Estonia and Latvia in a transnational context. Understandably, immigrants from Germany did not arrive with a clean slate. They brought with them continued connections with the German cultural space on several levels: family, university acquaintances, etc., not to mention the general cultural orientation. Hupel's actions, for example, attest to that which was capable of a man blessed with extraordinary talents. However, Hupel and his capacious effort are probably too contrasting an example of the arrival of the ideas of the Enlightenment in Estland and Livland. His interest in the physical environment of his new homeland, including the weather and climate conditions, is extraordinary in the context of the eighteenth-century tsarist Baltic provinces. There is no clear answer as to what were the sources of his creativity. Perhaps it was a constellation of motivating factors. The fact that he became a clergyman may have been the result of pragmatic calculations only. Nonetheless, his endeavour is an example of how cultural transfer worked: one-way. One of the dimensions of the concept of the world of the Enlightenment is vividly reflected in Hupel's activities: nature (in the sense of the physical, observable world) is an object of study, and wild nature is a force to be controlled. Similar attitudes could be expected of the young men of local origin who studied in German universities and returned to their homeland. Unfortunately, in the majority of cases sources are lacking, however, recourse will be made to those cases where this specific transfer of Enlightenment ideas to the Baltic provinces can be documented.

Collectively this had unquestionably powerful potential, but it is, of course, a question of the extent to which it could be implemented in practice, and whether it was really desired. Using some of the principles applied in prosopography would certainly help to gain a deeper insight. However, clarifying the possible "common face" of those trained in the German language and cultural space requires preliminary work with different types of source and is labour-intensive. At the same time, there are clear limits to prosopographical research. In history, at the level of the individual, the behaviour in a specific situation always remains decisive, and this is not predicted even when we have drawn the common face of a social layer or

9 Hupel, A. W. Topographische Nachrichten von Lief- und Ehstland. Gesammelt und herausgegeben durch August Wilhelm Hupel. Zweyter Band. Hartknoch, Riga, 1777, 7I. 
profession down to the last wrinkle. However, there is one type of source that, at least in theory, has the potential to explain the world perceptual patterns of Protestant pastors. Moreover, it provides opportunities to see clergy fulfilling not only their responsibilities to the congregation, but also a significantly more complex undertaking relating to congregation members and the surrounding environment, both spiritual and physical. I am referring to the materials deposited in the church archives.

This article is a case study that examines the patterns of filling Lutheran pastoral positions in the Latvian-language area of Livland province, i.e. historical Vidzeme, in the eighteenth century. The data of the Livland Pastors' Catalogue, ${ }^{10}$ which undoubtedly contain the most comprehensive basic information about clergy in positions - such as date and place of birth and death, education, activities in Livland before becoming a clergyman, and later as a clergyman - are principally relied upon. In addition, the catalogue contains data on family ties (marriages, children), which, if examined further, would reveal more about the way individuals from the German cultural space were rooted within local society. But, the same applies to those who had roots in either the Estland or Livland provinces, attended German universities, then returned to their homeland and entered into the clergy.

The volume of data in the compendium Die evangelischen Prediger Livlands bis IgI8 is large and provides preliminary information for explaining very different connections. As space for this article is limited, choices inevitably had to be made. The decision was to combine the data of a unique yet little exploited array of published sources with the data of Die evangelischen Prediger Livlands bis 1918 . Specifically, six source publications ${ }^{11}$ were published as proceedings of the Latvian State Archives in the period 1925-1934, which offer an overview of the surviving archives of I33 evangelical parish churches in both historical Vidzeme and Kurland. The archives of rural congregations were consolidated into the Latvian State Archives after the establishment of the Republic of Latvia. Lauma Juliana Sloka (1891-1960) was in charge of compiling the monumental source collection. According to the compiler's preface, the earlier documentation deposited during the period of validity of the Swedish Church

Io Die evangelischen Prediger Livlands bis 1918. Hrsg. von M. Ottow, W. Lenz. Böhlau, Cologne et al., 1977 .

II Sloka, L. Vidzemes draudžu kronikas. (Valsts archiva raksti, III.) Valsts arhīvs, Rīga, 1925; Sloka, L. Vidzemes draudžu kronikas. Otra dala. (Valsts archiva raksti, IV.) Valsts arhīvs, Rīga, 1927; Sloka L. Vidzemes draudžu kronikas. Treša dala. (Valsts archiva raksti, V.) Valsts arhīvs, Rīga, 1927; Kurzemes draudžu chronikas. Prima dala. (Valsts archiva raksti, VII.) Valsts arhīvs, Rīga 1928; Kurzemes draudžu chronikas. Otra dala. (Valsts archiva raksti, IX.) Valsts arhīvs, Rīga, 1930; Kurzemes draužu chronikas. Treša dala. (Valsts achiva raksti, X.) Valsts arhīvs, Rìga, 1934. 
Law of 1686 was subject to publication, i.e. the period from 1686 to I832, when the new Law for the Lutheran Church in the Russian Empire was enacted. ${ }^{12}$ The time frame established by the validity of the two church acts is somewhat conditional. The church archives also contain a small number of records and notifications from before the Swedish Church Law, not to mention the later period. At the time the Russian law for the Lutheran Church came into force in I832, pastors continued to perform their professional duties. Effectively, the Church Act of 1832 did not mean that pastors were replaced. The pastors, who had been appointed during the validity of the old Church Act continued their activities, including the keeping of church records. It is especially significant that the pastors still had the responsibility to record important events in the life of both the church and the congregation..$^{13}$ As this was continued in established church registers, the published entries exceed the period of validity of the Swedish Church Law.

The six-volume source publication is commonly called the "Church Chronicles". However, this is not a publication of chronicles in the sense we are accustomed to, but by agreement, the name does fit. The publication contains records of the things that "came to pass" in the life of a particular church and congregation, according to the chronological principle. Documents and parts of documents that, in the opinion of the compiler, fit into the framework of the general term chronicle have been transcribed. However, the publication also includes references to various types of material that have been deposited in church archives concerning the activities of the congregations (i.e. church inventories, lists of children who have received school education, records of estates belonging to the church manor, etc.). These materials have been published selectively. It is important, however, to note that Sloka has endeavoured to identify the author of such documentation, or at least during the term of which pastor they were incorporated into the church archives. In most cases, the author is a pastor who was responsible for keeping church records. However, there is also documentation of other provenance preserved in the church archives, as they directly relate to the activities of congregations. The present article is limited to the analysis of Vidzeme materials because church record-keeping in Courland developed under different conditions. Although it fell under the "wing of the Russian Eagle" in

I2 Sloka, L. Vidzemes draudžu kronikas. (Valsts archiva raksti, III.), V-VIII.

I3 Gesetz für die evangelisch-lutherische Kirche in Russland. Artikel I34-789 des Ersten Theils des Elften Bandes des Reichs-Gesetzbuches, Ausgabe des Jahres I857 aus der Russischen Urschrift in der II Abtheilung S.K.M. Eigener Kanzlei übersetzt. [n. p.], St. Petersburg, I857, Art. 344, 3 . 
1795, the Lutheran Church had a long historical tradition there from the sixteenth century. The Privilegium Gotthardinum, in which Gotthard Kettler (1517-1587) approved the Lutheran faith for his duchy in I570, was valid until the new Russian Law for the Protestant Church came into force in $1832 .{ }^{14}$ Thus, the system of keeping church archives in Courland was not harmonised until the first half of the nineteenth century.

The value of Vidzeme's published church archives as a historical source becomes clearer through the following short statistics. In total, the archives of 67 rural parishes have been deposited to the Latvian State Archives and have been partially published. The materials of the urban congregations operating in Vidzeme have not been published. The documentation preserved in the church archives is uneven in both quantitative and qualitative terms. For example, in the case of 13 church archives, the compiler Lauma J. Sloka has not been able to link the deposited documentation to the name of any pastor. A total of 154 parish clergymen can be identified in the pages of the publication. The inconsistency of the documentation stored in the church archives can be explained by the "difficult times" (or, societal stresses, such as wars, fires, etc.) and, in some cases, negligence in taking care to record the progress of the church and the congregation.

\section{A TOUR THROUGH PERSONAL HISTORY}

After incorporation into the tsarist state, the evangelical faith based on the Augsburg Confession was maintained in the Estland and Livland provinces. The act of capitulation concluded between the Livonian Knighthood and Field Marshal Boris Sheremetev (1652-1719) in 1710 affirmed that church life would remain on old foundations. ${ }^{15}$ Estland and Livland therefore remained open to the German cultural space also as provinces of the Russian Empire, and those Baltic Germans who studied theology at the universities in German lands could later come back to serve in local parishes, although their numbers were much too low to

I4 Hübner, M. Herzog und Landschaft: Die Verfassung im Herzogtum Kurland bis I6I7. Das Herzogtum Kurland I56I-I795. Verfassung, Wirtschaft, Gesellschaft. Bd. I. Hrsg. von E. Oberländer, I. Misāns. Nordostdeutsches Kulturwerk, Lüneburg, 1993, 29-56.

I5 Eesti rahva ajaloost Póhjasôja aastail I700-172I. Valimik dokumente. Eesti NSV Teaduste Akadeemia Ajaloo Instituut / Eesti NSV Riiklik Ajaloo Keskarhiiv. Tallinn, 1960, 288. Latest research on the capitulations: Die baltischen Kapitulationen von I7Io. Kontext - Wirkungen - Interpretationen. Hrsg. von K. Brüggemann, M. Laur, P. Piirimäe. (Quellen und Studien zur baltischen Geschichte, 23.) Böhlau, Cologne et al., 2014. 
alleviate the need to find clergy from Germany for local congregations. In fact, after the incorporation of Estland and Livland into the tsarist state, an interesting cultural situation emerged. German universities were highly valued in Russia, and many Russians also received their education there. Nevertheless, opportunities opened up for educated Germans to advance their careers in various professions within the tsarist state, and their breakthrough ability was impressive. There was no institution of higher education in the whole Russian Empire that would have provided theological education in the Protestant confession. Thus, it was common practice for both theology students who were not of local Baltic origin (who arrived as home teachers through universities) or locals returning home (who found employment) to register for a pastoral position in the provincial consistory. Conformation from the university that various professional subjects had been taken was not considered sufficient to secure a position as a pastor. Only an exam organised by a consistory provided quality assurance. Service as a home teacher was the primary challenge and a means by which an aspiring pastor could demonstrate their abilities. Character references provided by immediate employers were also taken into consideration, and favourable ones carried merit. Heinrich Bosse argues that an aspiring pastor had to demonstrate in their home teaching position whether he could put the knowledge he had acquired at university into practice. On the other hand, it always takes time to adapt, make connections and gain social capital. This was especially needed by those for whom Estland or Livland were terra incognita. One crucial requirement was added in view of the specifics of Estland and Livland: the service should also be provided in Estonian or Latvian. ${ }^{16}$ Proficiency in the peasant language equalised the chances of both locals and immigrants getting a job, to an extent. For example, a young local German competent in the dialect of the northern Estonian language area would probably have great difficulty serving the congregations of south Estonia.

The short reign of Tsar Paul I (I754-I80I) from I796-I80I can be described as a peculiar episode in the education and cultural life of the Russian Empire that also affected the appointment of the parish clergy in the Baltic provinces. In fear that the infiltration of the ideas of the Great French Revolution might shake the foundation of the tsarist regime, Tsar Paul I issued a number of decrees. After coming to power in 1796 , he demanded that foreigners no longer be hired in the service of the church because through them "unhealthy" ideas spread to Russia. 
The following year, Russian subjects were forbidden to go abroad to study and, during the same year, all students from the tsarist empire studying abroad were ordered to return home.

From a purely technical point of view, the decrees had a positive effect on the implementation of the career model (from a home teacher to a pastor) of local students who returned. As there was a constant shortage of home teachers and it was forbidden to recruit them from abroad, this made the competition according to the relation one foreigner-one local non-existent, for a while at least. Obtaining the position of home teacher did not take place now in consultation with the teaching staff of a German university; what counted were the connections and recommendations acquired locally. The shortage of home teachers and pastors increased. The short reign of Paul I can be assessed in several ways. On the one hand, it formed a prelude to the (re)opening of the University of Tartu in 1802 . It can even be said that it accelerated the establishment of the university. After he came to power in I8oI, Tsar Alexander I (1777-I825) overturned his father's decrees. The opening of the Faculty of Theology at the University of Tartu reduced the egress of local young men to German universities. There was also a drastic reduction in the need to hire home teachers from Germany, who in coming to the Baltic provinces would have taken a step up the career ladder by becoming a pastor. ${ }^{17}$

Based on the catalogue of personal data of Livland clergy, the following picture of the pastors of Vidzeme rural congregations can be drawn from those who have left a mark in the church archives. First of all, it would be what connections they have had with the Swedish University of Tartu, during the period of operation which ended in Pärnu (Ger. Pernau) in I7ı. From the available data, it is possible to identify pastors from Livland or Estland provinces in nine cases: eight from Livland and one from Tallinn (Ger. Reval)..$^{18}$ According to the catalogue, it is known from their education that only 3 or 4 pastors were limited to the University of Tartu. ${ }^{19}$ The rest also attended a number of German

I7 Tering, A. Eesti-, liivi- ja kuramaalased Euroopa ülikoolides, 62I-622.

I8 Die evangelischen Prediger, no I5IO: Andreas Reusner ( $1685-1764)$, born in Umurga (Ger. Ubbenorm); no 53: Johann Bachmann (? -1710), born in Valmiera (Ger. Wolmar); no II82: Paul Mey (1676-1739), born in Cēsis (Ger. Wenden); no 1565: Johann Gottfried Ruhendorf (?-I7IO), born in Trikāta (Ger. Trikaten); no I28I: Jakob Neudahl (I68I-I770), born in Vecpiebalga (Ger. Alt-Pebalg); no 1659, Eusebius Schoenland (1681?-1722), born in Riga; no 237: Johann Friedrich Buchmann (1676-1742), born in Burtniek (Ger. Burtneck); no 89: Georg Friedrich Baumgartner (I674-174I), born in Tallinn; no I283: Christian Gotthold Neuhausen (1684-1734), born in Cēsis.

I9 Die evangelischen Prediger, no II82: Paul Mey; no I565: Johann Gottfried Ruhendorf. Jakob Neudahl; may be also no 89: Georg Friedrich Baumgartner. 
universities (Wittenberg, Kiel, Leipzig, Greifswald, Halle) and, in one case, perhaps also Uppsala University. There were also two Vidzeme pastors who did not have roots in Livland, although they attended the University of Tartu during its brief Swedish period. ${ }^{20}$

Although there is little data for more detailed generalisations, it can be said that thanks to the Swedish University of Tartu, a layer of local intellectuals was being formed who were about to play an important role in the social hierarchy through their parish clerical positions. Whether the tendency proposed by a small sample is also confirmed in practice would, of course, require an overview of all the pastors who were associated with the University of Tartu. Unfortunately, this kind of overview is not available and would require special research.

In addition to these nine, how many pastors whose names are reflected in published church archives were also Livonians by birth? According to the catalogue, there were 79 of them. Seventy-five of the pastors came from outside Livland, from the German cultural space. It should be noted that eight pastors (including Michael Wittenburg and Heinrich Christian Wagner, who attended the University of Tartu during the Swedish period) $)^{21}$ had roots in Courland. ${ }^{22}$ Christoph Gerstenmeyer (1655-1727), from Międzyrzec in eastern Poland was born into a German family and studied at the universities of Frankfurt an der Oder and Königsberg. ${ }^{23}$

Of course, in the case of clergy, the education process is of importance because students sent to Livonia as home teachers were chosen by German university officials and the quality of university education varied. However, there are, of course, exceptions to the career model mentioned - the ascent from home teacher to pastor. It would be interesting to know how the universities of the German cultural space handled requests to send young intellectuals to Livland and Estland provinces. Unfortunately, due to the lack of preliminary work, it is currently not possible to give an overview of this process. Before examining the career model of eighteenth-century pastors, the role of the University of Tartu

20 Die evangelischen Prediger, no 2067: Michael Wittenburg (1668-1737), born in Courland, rector of Tartu town school, deported to Russia by the tsarist military in I708; no I981: Heinrich Christian Wagner (1664-1710), born in Trebnitz (Germany), studied also in Helmstedt, Leipzig and Jena.

2I Die evangelischen Prediger, no 2067; no 198I (see fn 19).

22 Die evangelischen Prediger, no 1799: Johann Ernst Stauwe (1700-1745), born in Īvande (Ger. Iwanden); no 442: Christoph Fabricius (1692-I723), born in Baldone (Ger. Baldohn); no. 2037: Friedric Wilhelm Weyrich (I788-1874), born in pastorate Sunākste (Ger. Sonnaxt); no 724: Evald Gottlieb Hentsch (I728-1780), born in Valdemārpils (Ger. Sassmacken) pastorate; no I415: Poelchau Joahann Daniel (173I-178I), born in pastorate Vircava (Ger. Würzau); no I416: Poelchau Johann Gotthrad (1737-I802), born in Vircava pastorate.

23 Die evangelischen Prediger, no 537. 
in training Vidzeme pastors needs to be ascertained. According to the data, 24 pastors who studied at the University of Tartu recorded biographical information in the Vidzeme church books. Twenty-one of them were born in Livland, ${ }^{24}$ two were from Germany, ${ }^{25}$ and one from Courland. ${ }^{26}$ Before becoming a pastor, eight of them held the position of home teacher or schoolmaster. ${ }^{27}$ Judging from this rather limited sample, the University of Tartu began to intervene in the reproduction of intellectuals for the purpose of satisfying the local need for human resources. Of all the pastors who have been identified in the church records of Vidzeme, 59 earned their living as home teachers. However, their career patterns are considerably varied, for example Benjamin Fürchtegott Balthasar Bergmann ( $1772-1856)$, who was born in Livland: went to university in Leipzig and Jena; was a home teacher 1795-1798, first in Riga then in 1798-1802 for a counsellor called Kontsharov in Moscow; I804-I805 was assistant pastor in Rūjiena (Ger. Rujen); I806-I8I4 was pastor in Ërg̣i (Ger. Erlaa); and, I8I4-I842, was pastor in Rūjiena. He defended his doctoral thesis in Tartu in I8I6, and was a member of several local societies both in Livland and in Germany (for example, at the University of Jena). Undoubtedly, he was a highly educated intellectual. ${ }^{28}$ Daniel Merckel (1714-1782) was born in Riga; attended the universities of Wittenberg and Helmstedt; was a home teacher in Hamburg; and became the pastor in Lēdurga-Turaida (Ger. Loddiger-Treyden) in 174I. ${ }^{29}$ Jakob Neudahl (168I-1770) was born in Livland; studied in Pärnu and Uppsala; was a home teacher in Stockholm; and became a pastor in 1727 in Vestiena (Ger. Festen). ${ }^{30}$ Librorius Stockfisch (1684-unknown) was born in Livland; studied in Rostock; was ordained in Pin,ki/Sala (Ger. Pinkenhof/ Holmhof) (I7I2-I742) but had to resign due to adultery, subsequently

24 Die evangelischen Prediger, no 202I, 746, 699, 999, I890, I859, I858, I841, 523, 562, II, I830, 2026, I834, I708, I267, 870, I23, 1607, 746, 928.

25 Die evangelischen Prediger, no 1363: Wilhelm Friedrich Parrot (I790-I872), born in Karlsruhe (Germany); no Io68: Georg Friedrich Lienig (1788-1866), born in Jürgensburg near Dresden.

26 Die evangelischen Prediger, no 2037: Friedrich Wilhelm Weyrich (I788-I874), born in pastorate Sunākste in Courland.

27 Die evangelischen Prediger, no 202I: Arnold Gottlieb Wellig (I778-I862), home teacher at the merchant Wiegandt in Tartu; no 999: Carl Friedrich Kybel (I796-1853), home teacher in Halliste (Ger. Hallist); no I858: Carl Jakob Julius Taurit (I822-I895), lecturer at the Kuhlmann Girls' School in Tartu; no 623: Johannes Heinrich Guleke (I82I-I889), home teacher at the manor Pantene in Mazsalaca (Ger. Salisburg) parish; no I830: Heinrich Wilhelm Stoll (1804-1885), home teacher in an unknown place; no 1068: Georg Friedrich Lienig (1788-1866), home teacher in Plātere manor (Ger. Weißensee) in the Madliena (Ger. Sissegal) parish; no I267: Carl Eduard Napiersky (1793-I864), born in Riga, home teacher in Vecpiebalga; no 870: Carl Ludwig Kaehlbrandt (I803-I888), home teacher in Kartūži manor (Ger. Schöneck) in the Nitaure (Germ. Nitau) parish.

28 Die evangelischen Prediger, no I23.

29 Die evangelischen Prediger, no 1166

30 Die evangelischen Prediger, no I28I. 
becoming a home teacher in Courland for many years. ${ }^{31}$ Andreas Riesner (unknown-I702) was born in Danzig; studied in Rostock; was a home teacher in Stockholm; then a deacon in Valmiera; and, from 1690 to I7OI(?), the pastor in Limbaži (Ger. Lemsal). Apparently, he was a man with a restless soul and politically suspicious in the eyes of the Swedish authorities, who arrested him in I70I. ${ }^{32}$

As can be seen from these short example biographies, individuals who became pastors attended numerous universities. Arvo Tering has emphasiszed the importance of the University of Jena in the education history of Estland and Livland. ${ }^{33}$ According to the catalogue, 45 future pastors studied at the University of Jena. ${ }^{34}$ This number includes those who additionally studied elsewhere. Among them, 26 pastors received their education only in Jena. Of these, 13 were born elsewhere and came to Livland. Also included was one with roots in Courland, and another with roots in Kuressaare (Ger. Arensburg). There is one pastor whose place of birth is unknown. Exactly the same number (13) of those born in Livland attended only the University of Jena.

There were 27 pastors who studied at the University of Königsberg. ${ }^{35}$ Surprisingly, 23 of them limited their education to Königsberg and only four attended universities elsewhere. The number of future Vidzeme pastors who studied at German universities other than Jena and Königsberg and have no local roots is significantly smaller. Of those born outside Livland province, six studied in Halle, and one also attended Königsberg. Five students studied in Leipzig, and four attended another university.

In addition to these statistics, the following could be concluded from the above analysis. Undoubtedly, every university that future pastors of Vidzeme attended had a particular spirituality. Each institution structured their theological studies according to their own syllabus, while faculties and lecturers were naturally composed of different people. In addition to basic professional knowledge, lecturers inadvertently mediated more general understandings of "how the world goes round", in accordance with their own individual outlook. It was also possible to partake of lectures in other faculties. Manifold intellectual impulses,

3I Die evangelischen Prediger, no I824.

32 Die evangelischen Prediger, no 1529.

33 Tering, A. Eesti-, liivi- ja kuramaalased Euroopa ülikoolides, 309.

34 Die evangelischen Prediger, no I383, 841, I825, I6I4, I799, II50, I895, I058, I37, I396, 819, I745, 359, 45I, 225, 26, IOOI, I23, I677, I290, I488, IO3I, 424, 436, I44363, I834, I352, 2018, 589 , I758, I5I2, I09I, 88, I660, 253, 759, I98I, I410, 332, I684, 585, I425, I353, I594.

35 Die evangelischen Prediger, no 408, I537, 537, I536, I584, I305, I370, 724, I816, 622, 644, I593, I82, I769, I306, I067, 2080, I759, I527, I4I5, I373, I986, I710, 557, 526, 2090, I386. 
interactions with fellow students, and the cultural environment of the university town - all must have shaped (or at least contributed to) the young person's perception of the world. Probably everyone who has attended a university would agree with this. Regrettably, opportunities to analyse these future Livland pastors from a psychological perspective are limited. In most cases, attempts to do so can be based on little more than assumptions. While the real content of transnational (or, indeed, transcultural) influence is certainly broader, at the core of its relative inaccessibility is the simple matter of whether or not individual pastors consider it important to record biographical information in church materials.

\section{ABOUT THE SELF-IMAGE OF PASTORS}

As previously described, Livland pastors can be grouped in a number of ways. We have done this on the principle of I) local/immigrant; 2) university education, or rather, which universities the pastors have attended; and, 3) an insight into the career model based on the principle of becoming a pastor after a period of working as a home teacher. Such a sociological differentiation technique is certainly reasonable. Unfortunately, this does not provide many opportunities to study pastors from a personality/psychological perspective. In other words, the pastors' catalogue only rarely reflects "life itself" and only in the event of extraordinary cases. ${ }^{36}$ In this sense, church archives are also potentially the source of the most vital information about pastors themselves. The provisions of Swedish Church Law in Estland and Livland are analysed in more detail below. It should be emphasised, however, that this law concerned the office and not the individual holding the office. The personal history reflections contained in the church records are first and foremost the spontaneous additions of the clergy and not obligatory

36 For example, see no I370: Johann Friedrich Pauli (1698-1749). He was born in Königsberg where he also studied at the university. He insulted his fellow pastors and loved to get drunk; 1306: Johann Wilhelm Nordhof (1736- ?) studied in Königsberg, was removed from his office as pastor and deprived of the right to work as such in 1765 due to drunkenness; no I824: Librorius Stockfisch (1684- ?), who was born in Riga and who attended the University of Rostock, he was arrested for adultery in 1742 , deprived of the right to work as a pastor, then worked as a home teacher in Courland; no I529: Andreas Riesner (? -1702), born in Danzig in I7oI, attended the University of Rostock, became a home teacher in Stockholm, deacon in Valmiera, was accused of professional misconduct, also politically suspicious, and was arrested in Tartu in I70I; no I758: Gottfried Johann Sixtel (? - I753), born in Riga, attended the universities of Jena and Rostock, was accused by peasants of oppression and cruelty; no 2040: Johann Matthias Wiener (1697-1777), was born in Sättelstädt in Thuringia, attended the University of Halle, and was a home teacher in Livland. It is not clear what the content of the complaints about him were. 
materials that were required to be recorded. The study of self-image is a complex task that a historian can perform only within the limits of his or her professional qualifications. Nevertheless, the basic data of the pastors' catalogue in the three main positions outlined above (local or immigrant, universities attended, career model) offer some insights. If the pastor has emphasised any of these aspects in his own handwritten notes, it has consequently been an important component of his identity. Identity is a changing phenomenon, but the cross-border effects must be taken into account in the case of those with roots in Livland who went to university in Germany, and probably even more so in the case of those born in German lands who migrated to Livland. There are not many handwritten notes which reflect these positions in the published Vidzeme church archives. It is therefore difficult (and somewhat ill-advised) to make sociological generalisations based on them. Nevertheless, they do provide an (albeit limited) insight into the pastors' self-image. Due to the lack of information, pastors' accounts of the activities of colleagues - found among the archival materials - are particularly helpful. These short personal reports offer not only clues as to the author's self-reflection, but also what they considered important of their predecessors.

How many pastors found it necessary to emphasise their previous position as a home teacher? There is a lack of such handwritten notes. However, several pastors who wrote reviews of the history of the parish in church chronicles considered it necessary to emphasise this biographical information. The pastor of Āraiši (Ger. Arrasch), Carl Friedrich Kyber (1796-1853), ${ }^{37}$ has provided a chronological overview of the activities of his predecessors. He highlights Friedrich Valentin Meder (I7I4-I769) as a remarkable example of the career of a home teacher. After the University of Jena, Meder, who was born in Riga, returned to Livland. He was employed as home teacher in the family of Pastor Johann Christoph Clare (1692-1743) in Otepää (Ger. Odenpäh); then a chamberlain at Zaube (Ger. Jürgensburg) Manor with the von Clodt family; and later became a home teacher in Cēsis. He was then invited to Āraiši by Count Aleksei Bestuzhev-Riumin (1693-1768), examined by Superintendent Jakob Andreas Zimmermann (1705-1770) in 1751, and immediately awarded the position of pastor. ${ }^{38}$

Johann Ludwig Börger (1730-I79I) notes of himself that, before becoming the pastor in Érǵeme (Ger. Ermes), he was a home teacher

37 Die evangelischen Prediger, no 999.

38 Die evangelischen Prediger, no II5o; Sloka, L. Vidzemes draudžu kronikas. (Valsts archiva raksti, III.), I2I-I22; from Meder's own hand, only economic documents have survived in the archives $(58,77-78,8 \mathrm{O}-8 \mathrm{I}, 83)$. 
in Mālpils (Ger. Lemburg). His employer was the von Taube family, and from there, he was invited to give a test sermon, after which he was awarded the pastoral position in Ērgeme..$^{39}$ Börger does not mention that he came from Königsberg and studied theology at the city's university. ${ }^{40}$ How he became a home teacher is not clear from the church archives. Börger's notes refer to Pastor Christian Heinrich Kyber (I734-1785) from Zwickau in Germany, who was a home teacher in Veckārki (Ger. Alt-Karkel) in 176I, before becoming the pastor in Ërgeme. ${ }^{41}$ There are no personal notes by Kyber himself in the church archives.

This raises the question of whether or not background and university education were prevalent in pastors' handwritten notes? Christoph Gerstenmeyer (1655-1727), who became pastor of Allaži-Vangaži (Ger. Allasch-Wangasch) in 1688, emphasises that he is from Międzyrzecz in Poland and that his inauguration in 1688 was attended by, among others, General Superintendent Johann Fischer $(\mathrm{I} 636-1705) .{ }^{42} \mathrm{He}$ does not talk about his university studies in Frankfurt an der Oder and Königsberg, nor about his career as a home teacher in Riga and Jelgava (Ger. Mitau). ${ }^{43}$ However, Joachim Pentin(us) (1648-1710) who became the pastor of the same church in 1702 did not write in his self-introduction a single word about the fact that he was born in Neubrandenburg, and attended university in Frankfurt an der Oder, Wittenberg, Jena and Kiel. ${ }^{44}$ The situation at the time of his appointment was extraordinary and did not necessarily encourage self-exposure. Specifically, the Russians completely destroyed his home church (von $d$. Russen totaliter ruiniert) in Lubana (Ger. Lubahn) and he was transferred to Allaži-Vangaži on the recommendation of Field Marshal Erik Dahlberg (1625-1703).45 Johann Michael Jacoby (1671-1739), who was born in Gottleuba, Saxony and attended the University of Jena, ${ }^{46}$ writes in a self-introduction in 1712 that he took office in difficult times (die zeiten sehr miserable). Jacoby did not add any lines to the church book that reveal anything more about himself. ${ }^{47}$

Pastor Paul Theodor Sanden (unknown-1796) writes about himself in the Aloja (Ger. Allendorf) church chronicle in I772: "I come from

\footnotetext{
39 Sloka, L. Vidzemes draudžu kronikas. (Valsts archiva raksti, IV.), 40.

40 Die evangelischen Prediger, no I82.

4I Sloka, L. Vidzemes draudžu kronikas. (Valsts archiva raksti, IV.), 5I; Die evangelischen Prediger, no rooo.

42 Sloka, L. Vidzemes draudžu kronikas. (Valsts archiva raksti, III.), II.

43 Die evangelischen Prediger, no 537.

44 Die evangelischen Prediger, no 1383.

45 Sloka, L. Vidzemes draudžu kronikas. (Valsts archiva raksti, III.), II.

46 Die evangelischen Prediger, no 84I.

47 Sloka, L. Vidzemes draudžu kronikas. (Valsts archiva raksti, III.), I2.
} 
Königsberg in Prussia, I was a home teacher in Nitau, where I was invited to Allendorf and where I have served as a pastor for nine years." 48 Sanden was in the position until $1796{ }^{49}$ In the church chronicles, Sanden began putting the term of office of Aloja pastors into chronological order, based on an old church book donated to the church by Baron Magnus Christianus von Ungern-Sternberg, who became the church patron in 1692. Sanden added supplementary records to the book and continued based on his archival finds. The list contains details of nine pastors, the last of whom was Sanden himself. For the first six pastors from the period 1644 to 1750 , Sanden has either not been able to identify their origin or places of education, or he did not consider it relevant. Nevertheless, he deemed it necessary to mention that Georg Leonhard Nordhof (1716-1766), who took office in 1750 , came from the town of Patten in Prussia and that his successor in 176I, Carl Wilhelm Jacobi (1736-177I), was born in the pastorate of Bērzaune (Ger. Bersohn)..$^{\text {so }^{\circ}}$ Johann Friedrich Schilling

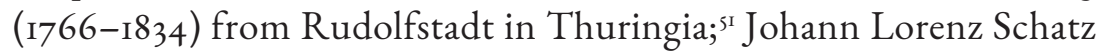
(1767-1847) from Arnstadt, (also in Thuringia); ${ }^{2}$ and, Arnold Gottlieb Wellig (1784-I862) who was born in Riga, all considered it necessary to supplement the list of pastors started by Sanden. ${ }^{53}$

It seems that the tradition initiated by Sanden that each new pastor write a short note about himself in the church book continued to be followed. From I8I2 to I843, Carl Gottlieb Schreiber (I769-I832), Friedrich Michael Hilde (I788-I845) and Ludwig Heerwagen (I817-I899) have made entries about themselves in the first person. None of them considered it necessary to emphasise their studies at any university. However, Hilde and Heerwagen write about their origins - both had roots in Livland province. ${ }^{54}$

Pastor Karl Friedrich Kyber (1796-1853) compiled a very informative overview of the clergy of Âraiši parish in $1827 .{ }^{55} \mathrm{He}$ concludes this thorough piece of writing by presenting his personal data, in which he highlights his admission to the University of Tartu in I8I4, where,

48 Sloka, L. Vidzemes draudžu kronikas. (Valsts archiva raksti, III.), 5o. The Latvian names of the places mentioned are Nitaure and Aloja.

49 Die evangelischen Prediger, no I548. It is not entirely clear whether in this case Königsberg is both place of birth and university.

so Sloka, L. Vidzemes draudžu kronikas. (Valsts archiva raksti, III.), so.

5I Sloka, L. Vidzemes draudžu kronikas. (Valsts archiva raksti, III.), 5o; Die evangelischen Prediger, no I6I4: he attended the University of Jena.

52 Sloka, L. Vidzemes draudžu kronikas. (Valsts archiva raksti, III.), so; Die evangelischen Prediger, no 1594: he was also a home teacher in Livland, although it is not clear where exactly. He attended the University of Jena.

53 Sloka, L. Vidzemes draudžu kronikas. (Valsts archiva raksti, III.), 5 I.

54 Sloka, L. Vidzemes draudžu kronikas. (Valsts archiva raksti, III.), 5 I.

55 Die evangelischen Prediger, no 999; Sloka, L. Vidzemes draudžu kronikas. (Valsts archiva raksti, III.), 9-I32. 
in his opinion, the foundation was laid for his education and personal development. From I8I7 to I819, he was a teacher in Halliste for the family of Provost Karl Ernst von Berg (1773-1833). He could have obtained a pastor's position as early as I819, but preferred to go abroad and study at the universities of Kiel and Berlin. He became the pastor in Âraiši in I821. ${ }^{56}$ However, it seems to be too simplistic to see the Halliste period in his life as an indispensable step on the career ladder from home teacher to pastor. The prestige of the Kyber family was high and his own talents so evident that he did not have to prove himself as a home teacher. Rather, his words seem plausible, that in Halliste he worked primarily on the collected materials preparing for the continuation of theological studies. ${ }^{57}$ What is undoubtedly important in Kyber's records is that, in his case, he did not fail to indicate his German roots. He was born in Ergli (Ger. Erlaa) pastorate in Livland, where his father Georg Friedrich (I769-1808) was a pastor, but his grandfather, Pastor Christian Heinrich Kyber (1734-1785) was an immigrant from Zwickau. ${ }^{58}$

Kyber's survey contains data on 26 pastors since the Reformation, beginning with Matthias Simonis (unknown-1704), who took office in 1674. During his tenure, the Swedish Church Law came into force, and according to Kyber, records from his own pen have also survived. Unfortunately, they are not directly reflected in the 1925 publication. In the case of Matthias Simonis, it is indicated that he came from Neumünster in Holstein. ${ }^{59}$ In 1704, Matthias Simonis' brother Samuel (unknown-1708?) continued as pastor of Āraiši. He was also born in Neumünster, and attended university in both Kiel and Tartu. It is not clear how Samuel Simonis became the pastor after his brother had died. Kyber complains that he has not made any notes in church records. ${ }^{60} \mathrm{His}$ successor was probably Johann Bachmann (unknown-17io), who died of the plague in I7IO, about whose background Kyber writes nothing. ${ }^{61}$ Christian Gotthold Neuhausen (1684-1734) was born in Cēsis, where his father was a pastor. He studied in Jena and was attached to the Āraiši congregation for a short time, from I7II to $1713 .{ }^{62}$ Emmanuel Sternberg (1680-1719) continued as pastor from 1713 to 1719 . Kyber writes that Sternberg was born in Danzig and was originally a field priest in the

56 Sloka, L. Vidzemes draudžu kronikas. (Valsts archiva raksti, III.), I32.

57 Sloka, L. Vidzemes draudžu kronikas. (Valsts archiva raksti, III.), I3I.

58 Sloka, L. Vidzemes draudžu kronikas. (Valsts archiva raksti, III.), I3O.

59 Sloka, L. Vidzemes draudžu kronikas. (Valsts archiva raksti, III.), II6-II7.

6o Sloka, L. Vidzemes draudžu kronikas. (Valsts archiva raksti, III.), II7: "Sonderbar ist es, dasz er das Kirchenbuch seines Bruders nicht fortgesetzt, überhaupt nicht einen einzigen schriftlichen Beweis seiner Amtswirksamkeit hinterlassen hat".

6I Sloka, L. Vidzemes draudžu kronikas. (Valsts archiva raksti, III.), II7.

62 Sloka, L. Vidzemes draudžu kronikas. (Valsts archiva raksti, III.), II7. 
Swedish army. ${ }^{63}$ However, Sternberg's education path is not explained. Paul Mey (1676-1739), in office from 1719 to 1722, was born in Riga and attended the University of Tartu ${ }^{64}$ Kyber does not provide detailed background information on the university studies of Christian von Hahn (unknown-173I), who was in office from 1722 to $1731 .{ }^{65}$ Johann Ernst Stauwe (1700-1745), born in Žievalti (Ger. Evalden), Courland, was pastor from 1733 to 1746 . According to Kyber, Stauwe excelled in the consistory exam. ${ }^{66}$ However, he makes no mention of Stauwe's studies at the university of Jena ${ }^{67}$ Johann Friedrich Pauli's (1698-1749) term in $\bar{A}$ raiši was short (1747-1749). He was probably a conflicted person with a penchant for alcohol and was probably appointed to Āraiši thanks to the patronage of Count Bestuzhev-Riumin. He used to be a pastor in various parishes, but was fired due to his complicated character. Kyber writes that Pauli was from Königsberg but he does not mention the fact that he went to university there. ${ }^{68}$ Friedrich Valentin Meder (1714-1769), the pastor from I75I to 1769 , was born in Riga, but Kyber considers it necessary to point out that his father was from Danzig. His career as a home teacher in Livland after university studies in Jena has been sketched previously. In the case of Johann Gottlieb von Linde (I74I-I80o), who was the pastor in Āraiši from 1770 to 177I, Kyber says that his roots are in Luckau, the capital of Lower Lusatia, and his studies at the University of Leipzig. His term as pastor in Āraiši was short. He not only failed to reach a consensus with the Latvian-speaking congregation, but also with parts of the local church council, and was forced to leave the congregation. Kyber does not mention that in 1765 , after arriving in Livland, he worked as a home teacher in Riga ${ }^{69}$ Gustav von Bergmann (1749-18I4) was a top intellectual who served as pastor in Âraiši from I77I to $178 \mathrm{o}$. Of all the pastors, Kyber devotes the most space to recounting Bergmann's merits and accomplishments. Bergmann was born in the pastorate of Ādaži (Ger. Neumühlen) in I749, where his father Balthasar was a pastor. He received his primary education at home and was then sent to study at a gymnasium in Weimar. Later he attended the University of Leipzig. Kyber again considers it necessary to take a genealogical tour in which he points out that Gustav von Bergmann's grandfather was

63 Die evangelischen Prediger, no I82I.

64 Sloka, L. Vidzemes draudžu kronikas. (Valsts archiva raksti, III.), II8-II9.

65 Sloka, L. Vidzemes draudžu kronikas. (Valsts archiva raksti, III.), II9; it is known, however, that he went to the University of Rostock: Die evangelischen Prediger, no 647.

66 Sloka, L. Vidzemes draudžu kronikas. (Valsts archiva raksti, III.), I2O.

67 Die evangelischen Prediger, no 1799.

68 Sloka, L. Vidzemes draudžu kronikas. (Valsts archiva raksti, III.), I2O; Die evangelischen Prediger, no 1370.

69 Sloka, L. Vidzemes draudžu kronikas. (Valsts archiva raksti, III.), I22-I23; Die evangelischen Prediger, no 1072. 
from Prussia. ${ }^{70}$ Karl Heinrich Eysingk (1753-I804), pastor from 1780 to 1787 , was born in Riga and studied both in Erlangen and Leipzig. ${ }^{71}$ Ernst Johann Adam Cornelius (I757-I820), pastor from 1787 to I819, was rooted in Franconia, from the town of Tann. He attended the University of Leipzig, but accepted the position of teacher with the von Coldt family in Jaunpils (Ger. Jürgensburg). From there he went on to study theology in Königsberg. ${ }^{72}$ The chronology compiled by Kyber has been continued by his successor Johannes Wilhelm Weyrich (1822-I888) on the basis of the same model. It is known from his self-introduction that he comes from near Valmiera, attended the University of Tartu, where he studied theology, and was a home teacher in Riga for some time. After passing the consistory exam, he held the position of clergyman in several places until becoming the pastor in Âraiši, after the death of Kyber in $1853 .{ }^{73}$

The church archives of Bērzaune (Ger. Bersohn) contain a self-introduction of Pastor Ewald Gottlieb Hentsch (1728-1780) and an overview of events in the parish up to 1779 . He was born in 1728 in Valdemārpils, Courland, to a pastor's family. In I730, his father was called to be the pastor in Lasdona (Ger. Lasdohn). He received his primary education through a home teacher and then attended the Riga Cathedral School. From 1747 to 1752 , he attended the University of Königsberg and was then a home teacher in Veclaicenes (Ger. Alt-Laitzen). He helped his old father serve as pastor in Lasdona, and from 1755 to 1762 , he was ordained in the same position. From 1763 to 1780 he was in office in Bērzaune. ${ }^{74}$

The pastor of Burtnieki, Johann Heinrich Guleke (I742-1816), in office from 1769 to 1816 , wrote about his inauguration. All he writes about himself is that he took office on May 3, I769, and immediately began running the church matriculation. ${ }^{75}$ Seemingly he meant the so-called church chronicle. However, it is known that Guleke was from Königsberg, attended university there, and was a home teacher at von Vietinghoff's in Straupe (Ger. Roop). ${ }^{76}$

70 Sloka, L. Vidzemes draudžu kronikas. (Valsts archiva raksti, III.), I23-I26.

Sloka, L. Vidzemes draudžu kronikas. (Valsts archiva raksti, III.), I27.

Sloka, L. Vidzemes draudžu kronikas. (Valsts archiva raksti, III.), I28.

Sloka, L. Vidzemes draudžu kronikas. (Valsts archiva raksti, III.), I33.

Sloka, L. Vidzemes draudžu kronikas. (Valsts archiva raksti, III.), I49-I50; it seems that the publication has slipped into a number of negligent mistakes in editing Hentsch's selfdescription. This concerns, above all, chronology. The data in Die evangelischen Prediger, no 724 , have been relied on here.

75 Sloka, L. Vidzemes draudžu kronikas. (Valsts archiva raksti, III.), I9I.

76 Die evangelischen Prediger, no 622. 


\section{INFORMATIVENESS OF VIDZEME CHURCH CHRONICLES}

In the introductory part of the article, the published materials of the rural congregations of the Latvian-speaking region of Livland province were characterized. It was stated that documentation is rather unevenly preserved. In 13 cases out of 67 church archives, we are not able to link the materials to a particular pastor. To further our understanding, it is first necessary to ascertain the protocol framework under which church materials were deposited. Above all, it must be understood in terms of the demands placed on the pastor in view of the so-called paperwork of the church and congregation.

After the capitulations of I7IO, the Swedish Church Law of 1686 remained in force in both Estland and Livland. ${ }^{77}$ This regulation sets out quite precisely what was expected from the Lutheran clergy. The obligation to keep a church book can be read from the Church Law, spoken of in the singular. Thus, a church book was kept, with all the necessary information about the life of the church and the congregation gathered between the covers. The information that the church book was supposed to contain can be read from the section of the Church Law that outlines what information the pastor must provide to the church visitors. ${ }^{78}$ The requirements for a candidate for pastor are also strict and every step in the pastoral office is regulated. ${ }^{79}$ Clear guidelines for behaviour are also given when the Almighty sends a plague or other infectious disease as punishment. ${ }^{80}$

After unification with Russia, the provisions of the Swedish Church Law governing the sacraments and ecclesiastical law remained in force. These passages, which covered most of the text of the Church Law, were intended for the daily life of the church congregation and continued to be followed, for example, at baptisms, communion, sermons, and pastoral confirmation ceremonies. However, Andres Andresen argues

77 Kirchen-Gesetz und Ordnung, so der Grossmächtigste König und Herr, Herr Carl, der Eiliffte, Dre Schweden, Gothen und Wenden König, etc. Im Jahr I686 hat verfassen und Im Jahrl 1687 im Druck ausgehen und publiciren lassen. Mit den dazu gehörigen verordnungen. J. G. Eberdt, Stockholm, [1687].

78 "Nachmals werden die Kirchenbücher fürgenommen in welchen unter gewissen Blättern und Titulne eingefürt werde." (Kirchen-Gesetz, I38). The seventh point is the requirement to record unusual environmental phenomena: "Was sich in dem Kirchspiel etwa ungemeines zugetragen und von einem oder anderen sonderlich gute oder böses betrieben worden oder wass ausser ordentlichen Lauf der Natur an den Elementen, oder an Lebendigen und Leblosen dingen sich ereignet hätte so zu verzeichnen würdig wäre.” (Kirchen-Gesetz, I39).

79 Kirchen-Gesetz, 95.

8o Kirchen-Gesetz, 87-88. 
that several principles provided by law lost their validity after I7io because the position of the church in society had changed significantly. ${ }^{81}$

It seems that the pastors kept the so-called church book, in which important events in the life of the congregation and the church were recorded, quite "innovatively". Let us recall the observations made in the section on self-image of the pastors in this article. It must be understood that each church had a different course of action, and the categories of information on which pastors made notes in the church records did not necessarily overlap. Understandably, the exchange of pastors led to changes of emphasis in the content of entries, as each pastor made records through the prism of a personal worldview. This makes it difficult to compare the content of the surviving church materials of the congregations. However, it is clear that the pastors' interest in writing about the relationship between the environment and the human world exceeded the requirements of the Swedish Church Law for many pastors. I consider the reason for this phenomenon to be the infiltration of Enlightenment ideas through university education in Germany. What was written depended on local circumstances and, of course, on the mindset of the pastor. However, no explanation was given as to why this was done. Church materials did not necessarily have to be a medium where pastors philosophised about the enlightening spirit of the age. The church records were to reflect, above all, the pastor's activities as a clergyman. Pastoral care in its broadest sense was their primary field of activity. As the deposited documentation also reflects a heightened interest in the realities of the secular world, it must be considered a feature of the Enlightenment.

The requirement to register extreme natural phenomena was, in some cases, overcome creatively by a systematic series of observations that reflect both extremes and normality. Unfortunately, we do not have the opportunity to take a closer look at the pastors' records made in the period before the Great Northern War, and to compare them with the period that began in I710. However, there is no reason to believe that the impulses to register the state of the physical environment would have been self-generated. Probably the extended perception of the world is manifested in the pages of the church materials. However, it must also be taken into account that the maintenance of rural pastors themselves depended upon the situation in agriculture. Therefore, phenological observations are also of practical importance. There is yet no other reason

8I Andresen, A. 1686. aasta Rootsi kirikuseadus Eesti- ja Liivimaa óiguskorralduses. Ajalooline Ajakiri, 1998, 3, 65-73. 
in the eighteenth century - no precepts of civil or ecclesiastical authorities, for example - to collect and mediate such information. Certainly, much depended on the pastor's persona, and what he considered worth writing down. We have received very informative chronical reports on the impact of weather on agriculture. ${ }^{82}$ Here are a few examples. The pastor of Lēdurga-Turaida, Philipp Wilhelm Haase (unknown-I739), ${ }^{83}$ wrote a fairly early series of nature observations entitled "Einige anmerckungen, was sich seit 1729 bisz 1738 inclusive sonderbares an jahreswitterungen zugetragen $u$. was solches für würckungen bey feld und garten früchten gehabt" ${ }^{84}$ A series of observations by the pastor of Burtnieki, Johann Heinrich Guleke, ${ }^{85}$ cover a later period and range from 1782 to $1816 .{ }^{86}$ Moreover, there are many details pertaining to the "novelty in the world view", transnational influences, and the continuing connections with the German cultural space that can be detected in the pastors' notes. What impulse, for example, led Zacharias Schroeter (I694-I777), the pastor of Kalsnava (Ger. Kalzenau), as far as known, to be the first of the Livland clergy in his years-long series of weather observations to use a thermometer as early as 1758 ? ${ }^{87}$ Could the encouragement to use cutting-edge technology in measuring air temperature have come from the intellectual environment of Livland in the middle of the eighteenth century? Hardly. Perhaps this is due to the fact that Schroeter came from near Jena, attended university there, and with the spiritual influences of one of the leading German universities at the time, became a keen observer of the environment. It can be assumed that the link with Germany was not interrupted. An indication of this being that in the middle of the eighteenth century, thermometers were not known to be manufactured in Livland, and he had probably obtained this instrument from Germany. Then there is Johann Eberhard Hinckeldey (1697-1748), who was born into the family of Johann Heinrich Hinckeldey (1663-1735), pastor of Rauna (Ger. Ronneburg). Hinckeldey Snr was born in Lübeck and attended the University of Wittenberg, ${ }^{88}$ however, his son Johann

82 An accurate overview of the weather conditions recorded by the pastors is provided in Vahtre, S. Ilmastikuoludest Eestis XVIII ja XIX sajandil (kuni I87o.a.) ja nende môjust pôllumajandusele ning talurahva olukorrale. - Eesti NSV ajaloo küsimusi VI. (Tartu Riikliku Ülikooli toimetised, 258.) Tartu Riiklik Ülikool, Tartu, 1970, 57-I37.

83 Die evangelischen Prediger, no 633; he was born in Schwedt, Germany, on the Polish border, went to university in Halle and then worked as a home teacher in Livland. He was pastor at Lēdurga-Turaida from 1724 to 1739.

84 Sloka, L. Vidzemes draudžu kronikas. (Valsts archiva raksti, V.), 4-I3.

85 Die evangelischen Prediger, nr. 622; he was born in Königsberg, attended university there, started working as a home teacher in Livland and was a pastor in Burtnieki for a long time, from 1769 to 1816 .

86 Sloka, L. Vidzemes draudžu kronikas. (Valsts archiva raksti, III.), 208-2II, 219-226, 23I-237.

87 Sloka, L. Vidzemes draudžu kronikas. (Valsts archiva raksti, IV.), 98.

88 Die evangelischen Prediger, no 758. 
Eberhard was a student at the University of Jena, where he received his master's degree. He assumed the role of pastor in Rauna after his father's death. ${ }^{89}$ Both the father and the son have recorded notes in a document called the Church Chronicle (Kirchenchronik), which they kept with loving care. Johann Eberhard Hinckeldey says that in December 1742, it was so cold that the professors of the Berlin Academy compared it with the severe winter of 1709: it was just a few degrees warmer than the winter of $1740 .{ }^{90}$ What does this entry tell us? Most probably, it tells us that Hinkeldey Jnr was in intellectual communication with German scientific circles.

\section{CONCLUSION}

The church archives deposited within the framework of the Swedish Church Law, parts of which have been published selectively in the early years of the interwar Republic of Latvia, are valuable source material for the study of Estonian and Latvian history. Although the Church Law of I686 provides the so-called obligation to keep church records succinctly, emphasising the need to provide an overview of particular aspects of the life of the congregation whenever requested, in addition to registering extraordinary events, church books gradually became a separate information-rich media. It must not be forgotten that the materials of church archives are not deposited by themselves. Behind each entry is a pastor, each with a unique sense of the world and an understanding of what is worth writing down and what is not. What role the pastors' individual backgrounds and education paths have played in shaping their worldview generally remains hidden. The spirit of the era, through which a more nuanced sense of the world is manifested, is beyond doubt. Enlightenment ideas arrived in Livland, albeit with some delay. Nonetheless, new ideas and thoughts can only travel through the mediation of people. Pastors trained in Germany inadvertently became brokers of new ideas and practices. However, it is quite natural that their application as a code of conduct may not be realised or remain hidden. It is difficult to find traces of the pastors' activities in the "conscious importation of enlightening ideas". Given that the nature of Enlightenment continues to be the subject of heated debate, ${ }^{91}$ the search for appropriate programmatic goals

89 Die evangelischen Prediger, no 759.

90 Sloka, L. Vidzemes draudžu kronikas. (Valsts archiva raksti, IV.), I22.

9I Forum. The German Enlightenment. - German History, 2017, 35, 3, 588-602. 
in pastors' activities would be a foothold into the nineteenth-century understandings of this phenomenon. Rather, it is possible to read from the writings of Vidzeme pastors about the infiltration of some elements of the new world of thought.

The author of the article considers his task fulfilled if the proposed discussion encourages a more meaningful understanding of the history of modern Estonia and Latvia in cross-border contexts. There is no doubt that Livland Lutheran pastors played a role in keeping the former Swedish provinces open to the influences of Western cultural tradition, once they had gone under the "wing of the Russian Eagle". It is, of course, a question of what sources and scientific procedures we should use in order to make the role of the clergy clearer.

\section{Acknowledgements}

This article has been prepared in the frame of the project funded by the Estonian Research Foundation IUT3I-6, A Transnational Setting for Estonian History: Transcultural Entanglements, International Organisations and Transborder Migrations ( $1^{\text {th }}-2 \mathrm{I}^{\mathrm{st}}$ Centuries). The author expresses his gratitude to James Baxenfield (Tallinn University) who not only proof-read the English translation of this article but also made some valuable comments on the text.

\section{LIIVIMAA PASTORITE ROLLIST I8. SAJANDI KULTUURIVAHETUSES}

\section{Priit Raudkivi}

Läti ja Eesti ajaloo iseloomulikuks jooneks oli 13. sajandist peale avatus saksa kultuuriruumi môjudele. Paljusid olulisi ühiskondlikke positsioone ei suudetud täita kohaliku inimressursi toel. Olukorra üheks pôhjuseks oli asjaolu, et siin ei kujunenud keskvôimuga riiklust, mis oleks loonud vajaliku infrastruktuuri, näiteks haridusasutuste näol, et koolitada haritlaskonda. Selles môttes on Läti ja Eesti ajalugu musternäide ühesuunalisest kultuuriülekandest. Tôsi, I632. aastal rajatud Tartu ülikool asus seda lünka küll täitma, kuid selle tegutsemisaeg jäi lühikeseks ja katkes suure põhjasõja käigus. Terve sajandi, kuni Tartu ülikooli (taas)loomiseni I8o2. aastal polnud siinmail vôimalik ülikooliharidust omandada. Seetôttu saadeti kohalikke noori ôppima 
Saksamaa ülikoolidesse. Kuid need, kes kodumaale tagasi tulid, ei rahuldanud kaugeltki kohalikke vajadusi ning seetôttu kutsuti ülikoolide vahendusel siia koduôpetaja ametisse ka Saksamaal sündinud noori. Teoloogiat tudeerinud noormehed moodustasid taimelava kohalikule pastorkonnale. Tôus koduôpetajast pastoriks pärast eksami sooritamist konsistooriumi juures oli Liivi-ja Eestimaal tavapraktikaks. Kuid andekad saksa kultuuriruumis hariduse saanud noored olid muljetavaldava läbilöögivõimega ka erinevates tsaaririigi ametites. Artiklis uuritakse Liivimaa kubermangu läti keeleala ehk ajaloolise Vidzeme maakihelkondade pastorikohtades täitmise mustreid I8. sajandil. Esmase biograafilise teabe pastorite päritolu, haridusliku tausta, perekondlike sidemete jm kohta annab 1977. aastal avaldatud Liivimaa pastorite kataloog. Teise allikana on kasutatud kolme 1925.-1927. aasta Läti riigiarhiivi toimetistena ilmunud Vidzeme maakihelkondade kirikumaterjalide publikatsiooni. Publitseerimist on leidnud ennekôike kroonikaline aines, mis peegeldab kiriku ja koguduseelu tähtsamaid sündmusi, enamasti kirikuôpetajate poolt kirja panduna. Kuid need materjalid on üliolulised môistmaks pastorite endi maailmataju ning minapilti. Nimetatud kahe allika andmestiku kombinatsioonis on püütud artiklis heita valgust järgmistele probleemidele. Esmalt on uurimise all tulevaste pastorite ülikoolihariduslik taust. Teiseks uurimisprobleemiks on pastorite minapilt ning ennekôike, kuivốrd oluliseks on nad pidanud oma ülestähendustes rôhutada isiklikku vôi ka eelkäijate haridusteed, päritolu (kas kohalik vôi sissrännanu) ja karjäärimudeli ülesehitust, näiteks koduópetajast pastoriks. Kolmandaks on püütud leida vastust küsimusele, kas Eesti- ja Liivimaal kehtinud rootsi kirikuseaduse (I686I832) ranges ettekirjutuslikus raamistuses ladestunud kirikukirjades vôib täheldada valgustusajastule iseloomuliku avardunud maailmataju elemente. Olgugi, et Vidzeme maakoguduste pastorite kroonikalaadseid ülestähendusi pole just palju, torkab nii mônelgi juhul silma kôrgendatud huvi keskkonnaseisundite, eriti ilma vastu ning seda saab pidada nüansseerituma maailmatunnetuse väljenduseks. Võib eeldada, et huvi füüsilise maailma ja selle ilmingute registreerimise vastu pole isetekkelised. Kindlasti on selle taga ülikoolidest saadud môjutused ning kohati ka jätkunud sidemed saksa kultuuriruumiga. Need impulsid ei pruugi ennast pastorite koostatud tekstides igal sammul sónaselgelt ilmutada, kuid varjatud kujul olid need kohal ning aitasid Liivi- ja Eestimaa hoida avatuna läänelikule kultuurile. 